\begin{tabular}{c} 
Volume and Issues Obtainable at Center for Sustainability Research and Consultancy \\
Journal of Accounting and Finance in Emerging Economies \\
ISSN: 2519-0318 ISSN (E) 2518-8488 \\
Volume 6: Issue 1 March 2020 \\
CSRᄃ \\
Journal homepage: www.publishing.globalcsrc.org/jafee \\
\hline
\end{tabular}

\title{
The Moderating Effect of OPEC and Non-OPEC on the Relationship Between Oil Price Volatility and Accrual Earnings Management in the Oil and Gas Industry
}

\author{
${ }^{1}$ Viveksarati Sandrasigaran, ${ }^{2}$ Jalila Binti Johari, ${ }^{3}$ Soh Wei Ni, ${ }^{4}$ Bany-Ariffin A.N \\ ${ }^{1}$ Ph.D Scholar, Department of Economics, Universiti Putra Malaysia, vivek1119@ hotmail.com \\ ${ }^{2}$ Department of Accounting and Finance, Universiti Putra Malaysia, jjohari@upm.edu.my \\ ${ }^{3}$ Department of Accounting and Finance, Universiti Putra Malaysia, sohweini@upm.edu.my \\ ${ }^{4}$ Department of Accounting and Finance, Universiti Putra Malaysia, bany@upm.edu.my
}

\begin{tabular}{l} 
ARTICLE DETAILS \\
\hline History \\
Revised format: February 2020 \\
Available Online: March 2020 \\
\hline Keywords \\
Political Costs, Price Setter, Price \\
Taker, Oil Price Volatility, \\
Accrual Earnings Management
\end{tabular}

JEL Classification:

D72, D79, E64

\begin{abstract}
This study is an empirical examination on the relationship between oil price volatility and earnings management in the oil and gas industry, moderated by dominant-firm, OPEC (Organization of Petroleum Exporting Nations), and fringe competition of Non-OPEC countries. This study tests current and non-current accruals as the proxy of accrual earnings management. A total sample of 209 firm-year observations from 2008 to 2018 of listed oil and gas firm collected from the Thomson Data stream database. To proxy the moderation effect, the samples divided into two sub-groups, OPEC and Non-OPEC. The initial results show that, overall, the interaction effect between OPEC/Non-OPEC and oil price volatility is significant to discretionary and income-decreasing discretionary accrual. This study contributes to existing earnings management literature regarding political cost, which remains a significant concern to oil and gas companies worldwide.
\end{abstract}

OPEN ACCESS

(C) 2020 The authors, under a Creative Commons Attribution-Non

Commercial 4.0

Corresponding author's email address: vivek1119@ hotmail.com

Recommended citation: Sandrasigaran, V., Johari, J. B., Ni, S. W. \& A.N, B. A., (2020). The The Moderating Effect of OPEC and Non-OPEC on the Relationship Between Oil Price Volatility and Accrual Earnings Management in the Oil and Gas Industry. Journal of Accounting and Finance in Emerging Economies, 6 (1), 283300

DOI: $10.26710 /$ jafee.v6i1.994

\section{Introduction}

Oil price volatility and its significant effect on the oil market has been an essential subject of academic interest. Many macroeconomic factors trigger oil price volatility, such as oil supply- oil demand, market speculation, geopolitical events, natural disasters (Kaufman et al.,2008; Florini and Sovacool, 2009; Martina et al., 2011). One of the frequently cited macroeconomic factors is the influence of OPEC (Organization of Petroleum Exporting Countries) as a unified group, widely viewed as the market power and Non-OPEC oil producers as the fringe competitors in the oil market (Rolf Golombek et al.,2018; Fattouh,2012; Bremond et al., 2012). 
OPEC member countries generate about 40 percent of the world's crude oil, and their oil exports roughly represent 60 percent of the total oil exported in the world (Energy Information Administration, 2019). The extent of OPEC's available production and spare capacity generally used as an indicator of influence on crude oil prices (Energy Information Administration, 2019). Given OPEC's market significance and geopolitical events deemed to cause potential loss of crude oil production can produce a sharp increase in oil prices (Energy Information Administration,2019). Meanwhile, non-OPEC oil producers only respond to market prices rather than attempting to influence prices by managing production. As a result of their independent decision, they are unable to control the market as they need to produce at full capacity. (Energy Information Administration, 2019). From the mid-2014 to early-2015, the price of Brent crude oil per barrel significantly dropped to $\$ 46$. This downfall attributed to the USA's increased shale production and OPEC's decision to keep its crude oil production stable.

Therefore, these current issues on the influence of OPEC and Non-OPEC on the crude oil market do raise serious questions about oil price volatility impact on the financial performance of oil and gas firms. Thus, this creates a motivation to analyze accrual earnings management in the oil and gas industry. Unlike cooking of the books, earnings management conforms to accounting standards procedures (Rahman \& Ali, 2006). Our research seeks to analyze the moderating effect of a dominant firm (OPEC) and fringe competitor (Non-OPEC) on the relationship between oil price volatility and accrual earnings management.

\section{Literature Review}

\subsection{Political Cost Theory}

The theory states that companies at heightened political scrutiny will engage in accounting choices that decreases reported earnings, as an attempt to reduce political sensitivities such as taxes or penalties (Watts and Zimmerman, 1978). After Watts and Zimmerman (1978), empirical studies have suggested a more extensive range of measures to proxy for political cost such as geopolitics, profits, rates of return, risk, capital intensity, industry concentration, industry membership, effective tax rates, number of employees, number of shareholders, labour intensity, press coverage, and even social responsibility disclosures (Zmijewski and Hagerman, 1981; Holthausen and Leftwich, 1983; Watts and Zimmerman, 1986; Deegan and Hallam,1991; Panchapakesan and McKinnon, 1992; Deegan and Carroll, 1993; Lemon and Cahan,1997; Han and Wang, 1998; Byard et al.,2007; Hsiao et al., 2016). In short, earnings are reduced downwards when there are political reasons to do so: e.g., firms in a politically sensitive industry such as the oil and gas industry are vulnerable to environmental concerns, antitrust allegations, and public perceptions of "excess profitability" (Ammr Kurdi, 2010). Significantly, the problem is complicated further by global geopolitical instability that causes crude oil supply disruptions, such as production cuts by OPEC (Ammr Kurdi, 2010).

Most previous studies on the oil industry examine the effect of a positive change in oil prices. Studies on the Persian Gulf crisis (Han and Wang, 1998), hurricanes Katrina and Rita (Byard, Hossain and Mitra, 2007), and the Arab Spring (Hsiao, Hu, and Lin, 2016) signal to income decreasing earnings management following several oil price shocks. Byard, Hossain, and Mitra (2007) and Han and Wang (1998) attribute their findings to the political cost hypothesis (Watts and Zimmerman, 1986). Cormier and Magnan (2002) analyze Canadian oil and gas firms for 12 years (1985-1996) using oil price volatility, found some evidence of systematic earnings management through nondiscretionary accruals. These studies signal that oil companies are willing to engage in earnings management, but their research is based on a specific country, e.g., North America. Thus, there is a significant gap in the works of literature as to how they would react to oil price volatility caused by the influence of OPEC as a dominant firm and Non-OPEC as the fringe competitor. 


\subsection{Dominant- Competitive Fringe Theory}

In a traditional Hotelling model of dominant-competitive fringe (1931), the crude oil market is positioned as a non-cooperative oligopoly market dominated by a few large suppliers with several small producers (David Newberry, 1981; R.Golombek et al., 2018). In the crude oil market, non-OPEC oil production driven by competitive behavior, and they are inelastic to oil price changes (Dées et al. 2007). Non-OPEC producers are typically reflected as the price taker, and thus produce at near full capacity with limited spare capacity (R.Golombek et al.2018). An increase in non-OPEC production will cause the oil price to decrease, and a decrease in their output causes the global aggregate output to fall.

On the other hand, OPEC plays the market balancing role and has the incentive to exercise market power and to reduce or increase crude oil production based on the market needs (von der Fehr, Nils-Henrik M., 2010; McKinsey Energy Insight, 2018). OPEC's behavior can be explained further by target revenue theory coined by (Ezzati,1976; Cremer and Isfahami, 1980; Teece, 1982), suggesting that target revenue is determined by the organization's ability to constraint production and maintain the production ceiling based on its reserves.

The theory ties with a study conducted by Dées et al. (2007), reveals that OPEC's behavior based on spare capacity utilization that significantly affects crude oil prices. Additionally, OPEC's price-setting ability depends on the elasticity of crude oil demand and supply, interest rates, and reserve level (Reza, 1984).

\section{Methodology}

\subsection{Data and Sampling}

Our sample is extracted from the Datastream- Public listed oil and gas companies covering the period of 2008 to 2018 through the Thomson Reuters Database. The sample followed two fundamental rules of thumb as per accordance with Sekaran (2003, p.295). Firstly, sample sizes should be larger than 30 and less than 500 firms. Secondly, a minimum sample size of 30 for each variable is necessary for subsampling. The initial sample of this study consists of 242 firm-year observations. Companies included in the final sample of 131 firm-year observations followed the conditions of (1) All financial data needed for the analysis are available (2) Meets the Jarque-Bera and Skewness/Kurtosis (3) No multicollinearity problems (4) White's test of Heteroscedasticity. Table 1 shows the final sample consists of listed oil and gas companies from Canada, Croatia, France, Indonesia, Netherlands, Thailand, the US, Gabon, Kuwait, Nigeria, and Saudi Arabia. These companies are divided into two separate dummy groups of OPEC and Non-OPEC based on reserves to production ratio of each selected countries.

Table 1: Distribution of listed oil and gas companies across countries

groupdummy $=$ NONOPEC

\begin{tabular}{|c|c|c|c|}
\hline $\begin{array}{c}\text { Domicile | } \\
\text { Country }\end{array}$ & Freq. & Percent & Cum. \\
\hline Canada & 12 & 13.04 & 13.04 \\
\hline Croatia | & 8 & 8.70 & 21.74 \\
\hline France & 10 & 10.87 & 32.61 \\
\hline Indonesia | & 7 & 7.61 & 40.22 \\
\hline Netherlands & 10 & 10.87 & 51.09 \\
\hline Thailand | & 7 & 7.61 & 58.70 \\
\hline US | & 38 & 41.30 & 100.00 \\
\hline
\end{tabular}




Total| $92 \quad 100.00$

groupdummy $=$ OPEC

\begin{tabular}{|c|c|c|c|}
\hline $\begin{array}{c}\text { Domicile } \\
\text { Country | }\end{array}$ & Freq. & Percent & Cum \\
\hline Gabon | & 2 & 5.13 & 5.13 \\
\hline Kuwait & 8 & 20.51 & 25.64 \\
\hline Nigeria| & 11 & 28.21 & 53.85 \\
\hline Saudi | & 18 & 46.15 & 100.00 \\
\hline Total | & 39 & 100.00 & \\
\hline
\end{tabular}

\section{Earnings management measurement}

In this study, total discretionary, current, and non-current accruals are used as the primary proxy of accruals earnings management following a previous earnings management study (Hsiao et al., 2016). We apply Han and Wang's and Byard's model for the computation of accruals as it captures the actual attributes and the industry specificity of oil and gas firms compared to other earnings management model (Hsiao et al.2016; Byard et al., 2007; Han and Wang, 2005). Specifically, discretionary, income decreasing, current and non-current accruals are calculated as follows:

a) Discretionary accrual measurement: TTACi,t/TAi,t $={ }^{\beta} 0+{ }^{\beta} 1(\Delta$ REVi, $t /$ TAi,t $)+{ }^{\beta} 2($ PPEi,,$/$ TAi,t $)+{ }^{\beta} 3($ lnSizei,t $)+{ }^{\beta 4}($ ROAi,t $)+{ }^{\beta 5}($ Leveragei, $t)+{ }^{\beta} 6($ Market to Book ratioi,t $)$ $+\varepsilon_{\mathrm{it}}$

b) Income decreasing discretionary accrual measurement: TTACi,t/TAi,t-1 $={ }^{\beta} 0+{ }^{\beta} 1(\Delta$ REVi,t $\Delta$ RECi,t $/$ TAi,t-1 $)+{ }^{\beta 2}($ PPEi, $/$ TAi,t-1 $)+{ }^{\beta 3}($ CFi,t/TAi,t-1 $)+{ }^{\beta 3}($ lnSizei,t $)+{ }^{\beta 4}($ ROAi,t $)$ $+{ }^{\beta} 5$ (Leveragei, $)+{ }^{\beta} 6$ (Market to Book ratioi,t $)+\mathcal{E}_{\text {it }}$

c) Current accrual measurement: CACi,t/TAi,t-1 $={ }^{\beta} 0+{ }^{\beta} 1($ REVi,t - RECi,t $/$ TAi,t-1 $)+{ }^{\beta} 2($ $\mathrm{CFi}, \mathrm{t} / \mathrm{TAi}, \mathrm{t}-1)+{ }^{\beta} 3(\ln$ Sizei,t $)+{ }^{\beta 4}($ ROAi,t $)+{ }^{\beta 5}($ Leveragei,t $)+{ }^{\beta} 6$ (Market to Book ratioi,t $)$ $+\varepsilon_{\text {it }}$

d) Non-current accrual measurement: NCACi,t/TAi,t-1 $=\beta_{0}+\beta_{1}($ PPEi, $, / T A i, t-1)+\beta_{2}($ CFi, t/TAi,t-1 $)+{ }^{\beta} 3(\ln$ Sizei, $t)+{ }^{\beta 4}($ ROAi,t $)+{ }^{\beta 5}($ Leveragei,t $)+{ }^{\beta} 6($ Market to Book ratioi,t $)$ $+\varepsilon_{\text {it }}$

Thus, our current study result should be consistent with prior earnings management studies (Hsiao et al.,2016; Byard et al.,2007; Kothari et al., 2005; Asbaugh et al.,2003; Cormier and Magnan,2002; Han \& Wang, 1998). Hence, we use the following model to analyze whether OPEC or Non-OPEC affects the relationship between oil price volatility and accrual earnings management.

DACCit $={ }^{\beta} 1+{ }^{\beta} 2\left(\mathrm{OPV}_{\mathrm{t}-1}\right)+{ }^{\beta} 3$ (group dummy) $+{ }^{\beta} 4$ (int_groupdummy_OPVT) $+{ }^{\beta} 5$ (NEG_CFO) $+{ }^{\beta} 6$ $($ LOSS $)+{ }^{\beta 7}$ (MeetBeat $)+\beta 8$ (CurrentRatio $)+\beta 9$ (Price) $+\beta 10$ (EBITDA margin $)+\beta 11$ (FCF) $+{ }^{\beta} 12$ (Sales Growth) $+\beta 13$ (Growth) $+\varepsilon_{\text {it }}$ 
DACCiit $={ }^{\beta} 1+{ }^{\beta} 2\left(\mathrm{OPV}_{\mathrm{t}-1}\right)+{ }^{\beta} 3($ group dummy $)+{ }^{\beta} 4($ int_groupdummy_OPVT $)+{ }^{\beta 5}\left(\mathrm{NEG} \_\mathrm{CFO}\right)+{ }^{\beta} 6$ $($ LOSS $)+\beta 7$ (MeetBeat) $+\beta 8($ CurrentRatio $)+\beta 9$ (Price) $+{ }^{\beta} 10($ EBITDA margin $)+\beta 11($ FCF $)+{ }^{\beta} 12$ (Sales Growth) $+{ }^{\beta} 13$ (Growth) $+\varepsilon_{\text {it }}$

CACCiit $={ }^{\beta} 1+{ }^{\beta} 2\left(\mathrm{OPV}_{\mathrm{t}-1}\right)+{ }^{\beta} 3($ group dummy $)+{ }^{\beta} 4$ (int_groupdummy_OPVT) $+{ }^{\beta} 5\left(\mathrm{NEG} \_\mathrm{CFO}\right)+{ }^{\beta} 6$ $($ LOSS $)+\beta 7$ (MeetBeat) $+\beta 8$ (CurrentRatio $)+\beta 9$ (Price) $+{ }^{\beta} 10($ EBITDA margin $)+{ }^{\beta} 11($ FCF $)+{ }^{\beta} 12$ (Sales Growth) $+{ }^{\beta} 13$ (Growth) $+\varepsilon_{\text {it }}$

NCACCiit $={ }^{\beta} 1+{ }^{\beta} 2\left(\mathrm{OPV}_{\mathrm{t}-1}\right)+{ }^{\beta} 3($ group dummy $)+{ }^{\beta 4}($ int_groupdummy_OPVT $)+{ }^{\beta 5}\left(\mathrm{NEG}_{-} \mathrm{CFO}\right)+{ }^{\beta} 6$ $($ LOSS $)+\beta 7$ (MeetBeat) $+\beta 8($ CurrentRatio $)+\beta 9($ Price $)+\beta 10($ EBITDA margin $)+\beta 11($ FCF $)+{ }^{\beta} 12$ (Sales Growth) $+{ }^{\beta} 13$ (Growth) $+\varepsilon_{\text {it }}$

Where $^{1}$

\begin{tabular}{|c|c|}
\hline Total Accrual & $\begin{array}{l}\text { (Net result - Operating Cash Flow) / Total } \\
\text { Assets }\end{array}$ \\
\hline Discretionary Accrual & Modified Jones Model Cross Sectional \\
\hline Current Accrual & $\begin{array}{l}\text { Income before extraordinary items }+ \\
\text { depreciation and amortization minus operating } \\
\text { cash flow/beginning of the year total assets) }\end{array}$ \\
\hline Non- Current Accrual & Total Accrual- Current Accrual \\
\hline Price & $\begin{array}{l}\text { Indicator variable that equals one if the oil } \\
\text { price is above USD50 for the current year and } \\
\text { zero, otherwise }\end{array}$ \\
\hline LOSS & $\begin{array}{l}\text { Indicator variable that equals one if the Net } \\
\text { result is negative in the current year and zero, } \\
\text { otherwise }\end{array}$ \\
\hline NEG_CFO & $\begin{array}{l}\text { Indicator variable that equals one if operating } \\
\text { cash flow is negative in the current year and } \\
\text { zero, otherwise }\end{array}$ \\
\hline EBITDA margin & $\begin{array}{l}\text { The EBITDA margin for firm i, at the end of } \\
\text { the fiscal year. (Extracted from Datastream) }\end{array}$ \\
\hline Current Ratio & Current Asset divided by Current Liability \\
\hline Meet/Beat & $\begin{array}{l}\text { Indicator variable that equals one if the firm's } \\
\text { income before extraordinary income at the time } \\
t \text { equals or greater than the previous year and } \\
\text { zero, otherwise }\end{array}$ \\
\hline Group dummy & $\begin{array}{l}\text { Dummy variable that indicates OPEC is } \\
\text { equaled to } 1 \text { and Non-OPEC is equaled to } 0 \\
\text { based on ratio to production ratio yearly }\end{array}$ \\
\hline Oil price volatility & $\begin{array}{l}\text { Oil Price volatility is converted into annual } \\
\text { data of (Dubai, WTI, and Brent). Secondly, it } \\
\text { is calculated using Ln (Current year/ Previous } \\
\text { year). Finally, it is computed using the } \\
\text { standard deviation of T-1 (Previous year to } \\
\text { current) }\end{array}$ \\
\hline Growth & $\begin{array}{l}\text { Entity I's total assets in the year } \mathrm{t} \text { divided by } \\
\text { the total assets in year } \mathrm{t}-1\end{array}$ \\
\hline
\end{tabular}




\begin{tabular}{|l|l|}
\hline Sales Growth & $\begin{array}{l}\text { Entity I's sales in the year t divided by the } \\
\text { sales in year t-1 }\end{array}$ \\
\hline Market to Book ratio & $\begin{array}{l}\text { Market capitalization divided by the book } \\
\text { value of Equity Book value of equity is } \\
\text { computed using the formula (Total assets } \\
\text { minus Total liabilities minus Intangible assets } \\
\text { minus Preferred Stock) }\end{array}$ \\
\hline Ln Size & $\begin{array}{l}\text { Firm size is computed using a log value of total } \\
\text { assets in year t }\end{array}$ \\
\hline
\end{tabular}

\section{Descriptive statistics and correlation results}

Table $2 \mathrm{a}$ and $2 \mathrm{~b}$ present the descriptive statistics and T-test statistics for model variables. Table $2 \mathrm{a}$ shows summary statistics for all the oil and gas listed companies, divided by OPEC and Non-OPEC firms. OPEC and Non-OPEC firms have 39 and 92 listed firms respectively. As presented in Table 2a, that Non-OPEC firms are larger in size (measured by Growth) compared to OPEC firms. They also have a significant mean value for Current Ratio (1.214) as compared to OPEC firms (1.119).

For the test of differences in Table $2 b$, all stated t-test values of each variable are two-sided. The results show that firms in the OPEC have higher discretionary ( $\mathrm{t}$-value $=-4.1370)$ and current accruals $(\mathrm{t}$-value $=$ -3.6972) compared to Non-OPEC indicates that there is a high number of small oil and gas firms within the sample. Meanwhile, T-stat reveal that income decreasing $(\mathrm{T}$-value $=4.2695)$ and non-current discretionary accruals $(\mathrm{T}$-value $=6.0828)$ is highly associated with large-size Non-OPEC firms. The rest of the results are presented below.

Table 2a: Descriptive Statistics

i) OPEC

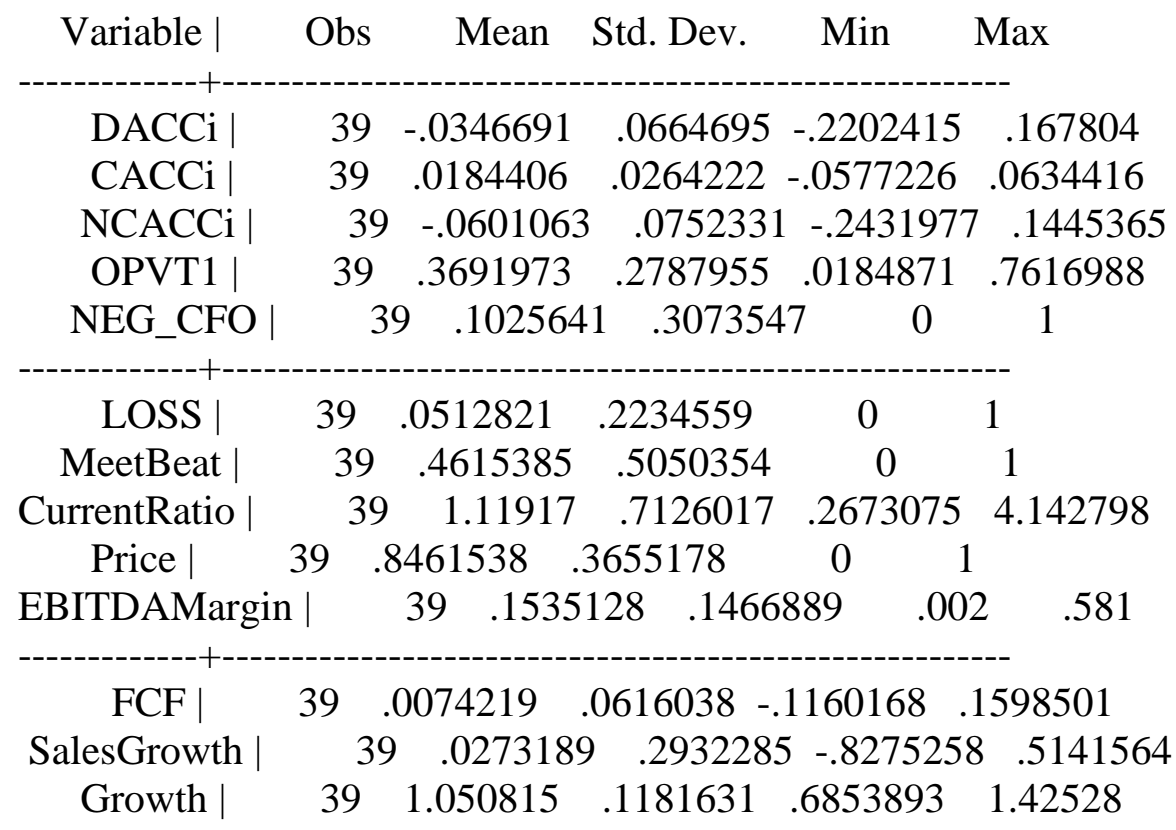


ii) Non- OPEC

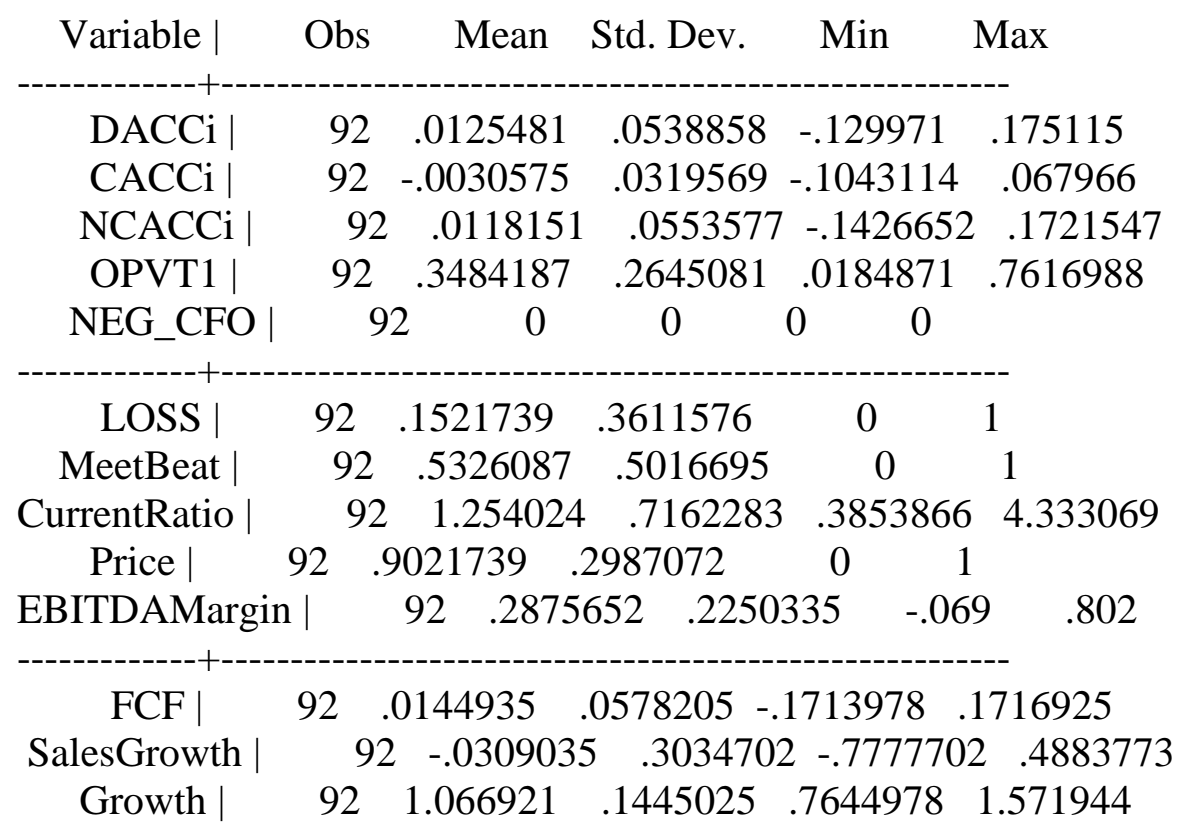

Table 2b: T-Test of differences comparing OPEC and Non-OPEC

\begin{tabular}{|l|l|l|l|l|l|}
\hline \multirow{2}{*}{ Variables } & \multicolumn{2}{l}{ OPEC } & \multicolumn{2}{l|}{ NON-OPEC } & $\begin{array}{l}\text { Test of } \\
\text { Differences }\end{array}$ \\
\cline { 2 - 6 } & $\mathrm{N}$ & Mean & $\mathrm{N}$ & Mean & T-Stat \\
\hline DACC & 39 & 0.02184 & 92 & -0.01315 & $-4.1370^{* * *}$ \\
\hline DACCi & 39 & -0.03466 & 92 & 0.01254 & $4.2695^{* * *}$ \\
\hline CACCi & 39 & 0.01844 & 92 & -0.003057 & $-3.6972^{* * *}$ \\
\hline NCACCi & 39 & -0.06010 & 92 & 0.011815 & $6.0828 * * *$ \\
\hline OPVT1 & 39 & 0.3692 & 92 & 0.3484 & -0.4046 \\
\hline NEG_CFO & 39 & 0.1026 & 92 & 0.00 & $-3.2177^{* * *}$ \\
\hline LOSS & 39 & 0.05128 & 92 & 0.1522 & 1.6163 \\
\hline MEETBEAT & 39 & 0.4615 & 92 & 0.5326 & 0.7399 \\
\hline $\begin{array}{l}\text { CURRENT } \\
\text { RATIO }\end{array}$ & 39 & 1.1192 & 92 & 1.2540 & 0.9869 \\
\hline PRICE & 39 & 0.8462 & 92 & 0.9022 & 0.9166 \\
\hline $\begin{array}{l}\text { EBITDA } \\
\text { MARGIN }\end{array}$ & 39 & 0.1535 & 92 & 0.2876 & $3.4208 * * *$ \\
\hline FCF & 39 & 0.00742 & 92 & 0.0145 & 0.6277 \\
\hline $\begin{array}{l}\text { SALES } \\
\text { GROWTH }\end{array}$ & 39 & 0.02731 & 92 & -0.03090 & -1.0140 \\
\hline GROWTH & 39 & 1.051 & 92 & 1.067 & 0.6140 \\
\hline
\end{tabular}

Significant at a two-tailed $\leq 0.01$ 
Table 3 represents the contemporaneous accrual correlations between oil price volatility and accrual earnings management. As seen in Table 3, Non-OPEC exhibits a high correlation at a five and ten percent percent confidence for discretionary, income decreasing and non-current accrual. Meanwhile, OPEC is not correlated with discretionary, income decreasing accrual, current, and non-current accrual.

Table 3: Contemporaneous accrual correlation at 5 percent confidence level

\begin{tabular}{|c|c|c|c|c|c|c|c|}
\hline \multicolumn{2}{|c|}{$\begin{array}{l}\text { Discretionary } \\
\text { and OPVT1 }\end{array}$} & \multicolumn{2}{|c|}{$\begin{array}{l}\text { Income } \\
\text { Decreasing } \\
\text { Discretionary } \\
\text { Accrual and } \\
\text { OPVT1 }\end{array}$} & \multicolumn{2}{|c|}{$\begin{array}{l}\text { Current Accrual and } \\
\text { OPVT1 }\end{array}$} & \multicolumn{2}{|c|}{$\begin{array}{l}\text { Non-Current Accrual and } \\
\text { OPVT1 }\end{array}$} \\
\hline OPEC & \begin{tabular}{|l|} 
NON- \\
OPEC
\end{tabular} & OPEC & $\begin{array}{l}\text { NON- } \\
\text { OPEC }\end{array}$ & OPEC & \begin{tabular}{|l|} 
NON- \\
OPEC
\end{tabular} & OPEC & \begin{tabular}{|l|} 
NON- \\
OPEC \\
\end{tabular} \\
\hline 0.0337 & $0.2436 * *$ & $\begin{array}{l}- \\
0.0782\end{array}$ & $-\overline{0.2386 * *}$ & 0.1623 & -0.1054 & -0.0995 & $-0.1816^{*}$ \\
\hline- & 0.0193 & - & 0.0220 & - & - & - & 0.0832 \\
\hline
\end{tabular}

$* *$, Significant at a two-tailed $\leq 0.05,0.10$

Before running the primary regression, we have made sure that we ran several tests such as the JarqueBera normality test, skewness, and kurtosis test of normality, White's test of heteroscedastic and Variance Inflation Factor for multi-collinearity. All the results revealed that our data is free from outliers, and they are normally distributed, homogenous, and free from multi-collinearity. The results are enclosed in the Appendix.

\section{Empirical Results}

We hypothesize that OPEC and Non-OPEC are able to moderate the relationship between oil price volatility and accrual earnings management. We test the hypothesis using the models as discussed in Section 4. We follow the similar research methods steps from Hsiao et al., (2016); Byard et al.,(2007); Cormier et al., (2003); Han and Wang (1998) to estimate earnings management equations. We find that it is reasonable to examine the firm-level earnings management behavior based on market grouping as there is a significant difference in terms of geopolitical effect between OPEC and Non-OPEC in the crude oil market.

As shown in Column (a) and (b) of Table 4, the coefficient estimate of OPEC's moderation effect with oil price volatility with discretionary accrual (coefficient $=-0.0658$ ) and income decreasing discretionary accrual (coefficient $=0.753$ ) is significant at one and five percent level indicates that OPEC firms predict higher negative discretionary accruals compared to Non-OPEC firms during crude oil price volatility. These findings are fair with the dominant-competitive fringe theory. Hochman and Zilberman (2011) explain that OPEC is seen as the dominant price-setter with high proven crude oil reserves compared to Non-OPEC firms, and able to impose production quotas to its member countries and also non-member countries. OPEC are able to target revenue-based through spare capacity utilization compared to NonOPEC, who required to produce at full capacity in order to bring production costs lower (Kaufman et al., 2008; R.Golombek et al.2018). Thus, this strengthens the notion that OPEC firms engage in negative and income decreasing accruals higher compared to Non-OPEC firms to manage oil price volatility as NonOPEC firms produce at full capacity to reduce production costs. This analysis also provides substantial evidence that oil price volatility is highly significant with accrual earnings management behavior amongst oil and gas firms as a whole. The majority of predicted control variables are relatively significant in explaining the strength of the accruals method used. 
Table 4: Regression result of Accruals

\begin{tabular}{|c|c|c|c|c|}
\hline a) Discretionary Accrual & & $\begin{array}{ll}\text { b) } & \text { Income } \\
\text { Decreasin } \\
\mathrm{g} \\
\text { Discretion } \\
\text { ary } \\
\text { Accrual } \\
\end{array}$ & $\begin{array}{l}\text { C) Current } \\
\text { Accrual }\end{array}$ & $\begin{array}{l}\text { d) Non- } \\
\text { Current } \\
\text { Accrual }\end{array}$ \\
\hline Variables & P-value & P-value & P-value & P-value \\
\hline OPVT1 & $0.003 * * *$ & $0.003 * * *$ & $0.073 *$ & $0.022 * *$ \\
\hline Groupdummy-OPEC & $0.003 * * *$ & $0.003 * * *$ & 0.202 & $0.000 * * *$ \\
\hline Groupdummy_OPEC*OPVT1 & $-0.008 * * *$ & $0.048 * *$ & 0.149 & 0.143 \\
\hline $\begin{array}{l}\text { Groupdummy_NONOPEC*OPVT } \\
1\end{array}$ & $0.008 * * *$ & $-0.048 * *$ & -0.149 & -0.143 \\
\hline NEG_CFO & $0.027 * *$ & 0.574 & $0.000 * * *$ & $0.004 * * *$ \\
\hline LOSS & $0.000 * * *$ & $0.003 * * *$ & $0.001 * * *$ & $0.001 * * *$ \\
\hline MeetBeat & 0.533 & 0.700 & $0.081 *$ & 0.285 \\
\hline Current Ratio & 0.481 & 0.818 & $0.001 * * *$ & 0.352 \\
\hline Price & $0.030 * *$ & 0.793 & 0.762 & 0.874 \\
\hline EBITDA Margin & $0.000 * * *$ & $0.000 * * *$ & $0.003 * * *$ & $0.000 * * *$ \\
\hline FCF & $\begin{array}{l}0.000 * * * \\
*\end{array}$ & $0.015^{* *}$ & 0.130 & $0.008 * * *$ \\
\hline Sales Growth & 0.166 & $0.075 *$ & $0.002 * * *$ & 0.347 \\
\hline Growth & $0.000 * * *$ & 0.181 & 0.169 & 0.783 \\
\hline
\end{tabular}

$* * * . * * . *$ Significant at a two-tailed p-value $\leq 0.01,0.05,0.10$

\section{Conclusion}

This paper examines the use of discretionary, income decreasing discretionary, current and non-current accruals as a proxy of accrual earnings management to explain earnings management prevalence to manage oil price volatility. This study also looks into the geopolitical effect by introducing group classification of OPEC and Non-OPEC as the moderator effect. Specifically, most of the prior earnings management works of literature are based on the notion that earnings management is merely focused on a firm and industry level. Thus, the study initially posits that firms in either OPEC or Non-OPEC have an inverse moderating effect on the relationship between oil price volatility and earnings management and vice versa. This research, therefore, provides a basis for accepting the null hypothesis that presumed that OPEC or Non-OPEC is significant in strengthening or weakening the effect of oil price volatility and earnings management for the discretionary and income-decreasing discretionary accrual model. Meanwhile, the rest of the accruals model is insignificant in affecting the relationship.

Additionally, it must be noted that we are only using the reserve to production ratio as a proxy for OPEC and Non-OPEC, a country level variable rather than a firm-level variable to explain the effect of OPEC and Non-OPEC. We agree that additional indicators required to capture the true essence of the impact of OPEC and Non-OPEC, for instance, supply and demand for crude oil and interest rate exchange (Reza,1984). Extending with the prior research conducted by Hsiao et al., (2016), this study provides evidence that oil and gas firms in OPEC and Non-OPEC have an inverse relationship in explaining the association between oil price volatility and earnings management via current accruals. The rest of the control variable results are in line with previous studies (Hsiao et al., 2016; Ammr Kurdi, 2010; Byard et al., 2007; Han and Wang, 1998) 
The findings of this paper contribute to the earnings management research that examines the political cost hypothesis by showing how OPEC and Non-OPEC group classification affects the relationship between oil price volatility and accrual earnings management. These results are of interest to regulators that are interested in understanding how oil and gas companies manage oil price volatility through reported earnings.

\section{Limitation of research}

This research is limited by sample constraints while engaging in a comparison study. There was a limited number of listed firms in the OPEC region, and they are moderately small in size in terms of market capitalization as compared to Non-OPEC firms. Therefore, results may significantly limit the generalization of the presented results per the group classification of OPEC and Non-OPEC. Further research needed with an equal extensive sample to model all known and relevant variables for the moderation effect of OPEC and Non-OPEC.

\section{Reference}

Ashbaugh-Skaife, H., LaFond, R., \& Mayhew, B (2003). Do non-audit services compromise auditor independence? Further evidence. The Accounting Review 78 (3): 217-250

Brémond, V., Hache, E., Mignon, V. (2012). Does OPEC still exist as a cartel?. An empirical investigation. Energy Econ. 34, 125-131

Byard, D., Hossain, M. and Mitra, S. (2007), “US oil companies' earnings management in response to hurricanes Katrina and Rita," Journal of Accounting and Public Policy, Vol. 26 No. 6 pp. 733-748

Cormier, D., and Magnan, M. (2003), "Performance reporting by oil and gas firms: contractual and value implications," Journal of International Accounting, Auditing, and Taxation, Vol. 11 No. 2, pp. 131-153

Cremer, J.S., Isfahami, S. (1980). A Competitive Theory of the Oil Market: What Does OPEC Really Do? University of Pennsylvania. Working Paper No 80-4

Deegan, C. \& Carroll, G. (1993). "An Analysis of Incentives for Australian Firms to Apply for Reporting Excellence Awards," Accounting and Business Research, Vol. 23, No. 2, pp. 219-227

Deegan, C. \& Hallam, A. (1991). "The Voluntary Presentation of Value Added Statements in Australia: A Political Cost Perspective," Accounting and Finance, Vol. 31, No. 1, pp. 1-21

Dees, S., Karadeloglou, P., Kaufmann, R.K., Sanchez, M. (2007). Modeling the world oil market: assessment of a quarterly econometric model. Energy Policy 35,179-191

EIA.(2019), Oil: Crude and petroleum explained- Oil Prices and Outlook https://www.eia.gov/energyexplained/oil-and-petroleum-products/prices-and-outlook.php

Ezzati, A. (1976). Future OPEC price and production strategies as affected by its capacity to absorb oil revenues. Eur. Econ. Rev. 8, 107-138

Fattouh, B., Mahadeva, L. (2013). OPEC: what difference has it made? Ann. Rev. Resour. Econ. 5, 427-443

Florini, A. and Sovacool, B. K. (2009) Who governs energy? The challenges facing global energy governance. Energy Policy, 37, 5239-5248

Golombek, G., Irarrazabal, A.A., and Ma, L. (2018). OPEC's market power: An empirical dominant firm model for the oil market. Energy Economics, 70, 98-115

Han, J. and Wang, S. (1998), "Political costs and earnings management of oil companies during the 1990 Persian Gulf Crisis", The Accounting Review, Vol. 73 No. 1, pp. 103-117

Holthausen, R. W. \& Leftwich, R. W., (1983) “The Economic Consequences of Accounting Choice: Implications of Costly Contracting and Monitoring,” Journal of Accounting and Economics, Vol. 5, August, pp. 77-117

Hotelling, H., 1931. The economics of exhaustible resources. J. Polit. Econ. 39 (2), 137-175

Hochman, G., \& Zilberman, D. (2011). The political economy of OPEC

Hsiao, D., Hu, Y. \& Lin, J.W. (2016). The earnings management opportunity for US oil and gas firms during the 2011 Arab Spring event. Pacific Accounting Review, 28(1), 71-91.

Kaufmann, R.K., Bradford, A., Belanger, L.H., Mclaughlin, J.P., Miki, Y., (2008). Determinants of OPEC 
production: implications for OPEC behavior. Energy Econ. 30, 333-351.

Kothari, S., Leone, A. and Wasley, C. (2005), "Performance matched discretionary accruals measures," Journal of Accounting and Economics, Vol. 39 No. 1, pp. 163-197

Kurdi, A. (2010), "Regulations and political costs in the oil and gas industry: an investigation of discretion in reporting earnings and oil and gas reserves estimates," Unpublished doctoral dissertation, University of North Texas

Lemon, A. J. \& Cahan, S. F., (1997) "Environmental Legislation and Environmental Disclosures: Some Evidence from New Zealand," Asian Review of Accounting, Vol. 5, No. 1, pp. 78-105

Martina, E., Rodriguez, E., Escarela-Perez, R. and Alvarez-Ramirez, J. (2011) Multiscale entropy analysis of crude oil price dynamics. Energy Economics, 33, 936-947

McKinsey Energy Insights. (2018). "Refinery Reference Desk: Call on OPEC Capacity." https://www.mckinseyenergyinsights.com/resources/refinery-reference-desk/call-on-opec-capacity/.

Panchapakesan, S. \& McKinnon, J., (1992) "Proxies for Political Visibility: A Preliminary Examination of the Relation Among Some Potential Proxies,” Accounting Research Journal, Spring, pp. 71-80

Rahman, R. A., Ali, F. H. M., (2006). Board, Audit Committee, Culture, and Earnings Management: Malaysian Evidence. Managerial Auditing

Journal, 21(7), 783-804

Reza, A.M. (1984). “The price of oil and conflict in OPEC.” Energy Journal 5: 29-33.

Sekaran, U. (2003), Research methodology for business

Teece, D. (1982). OPEC behavior: an alternative view. In: Griffin, J.M. (Ed).., OPEC Behavior and World Oil Prices. Allen \& Unwin, London

von der Fehr, Nils-Henrik M. (2010) Leader, or just dominant? The dominant-firm model revisited, Memorandum, No. 2010,15, University of Oslo, Department of Economics, Oslo

Watts. R.L. \& Zimmerman. J.L., (1978), “Towards a Positive Theory of the Determination of Accounting Standards,” The Accounting Review, Vol. 53, No 1, pp. 112-134

Watts. R.L. \& Zimmerman. J.L., (1986), Positive Accounting Theory, Prentice-Hall, London

Zmijewski, M.E., and Hagerman, R.L., (1981), "An Income Strategy Approach to the Positive Theory of Accounting Standard Setting Choice,” Journal of Accounting and Economics, Vol. 3, pp. 129-149 


\section{$\underline{\text { Appendix }}$}

i. Test of Normality:

a) Jarque-Bera Normality test

Jarque-Bera normality test: 3.173 Chi(2) .2047

Jarque-Bera test for Ho: normality:

b) Shapiro-Wilk W test for normality

$\begin{array}{cccccc}\text { Variable | } & \text { Obs } & \text { W } & \text { V } & \text { z } & \text { Prob>z } \\ \text { residstd | } & 131 & 0.98437 & 1.620 & 1.086 & 0.13872\end{array}$

c) Skewness/Kurtosis tests for Normality

\section{ii. Heteroskedasticity test:}

White's test for Ho: homoskedasticity against Ha: unrestricted heteroskedasticity

$$
\operatorname{chi} 2(113)=129.25
$$

Prob $>$ chi $2=0.1408$

Cameron \& Trivedi's decomposition of IM-test

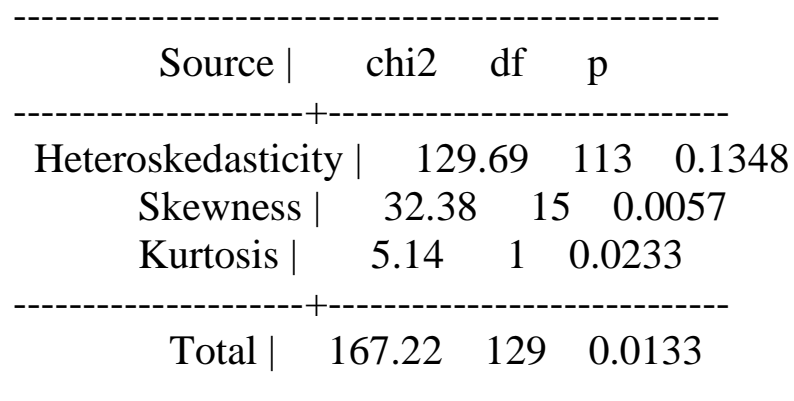




\section{iii. Test of Multi-Collinearity Variance Inflation Factor}

a) DACC

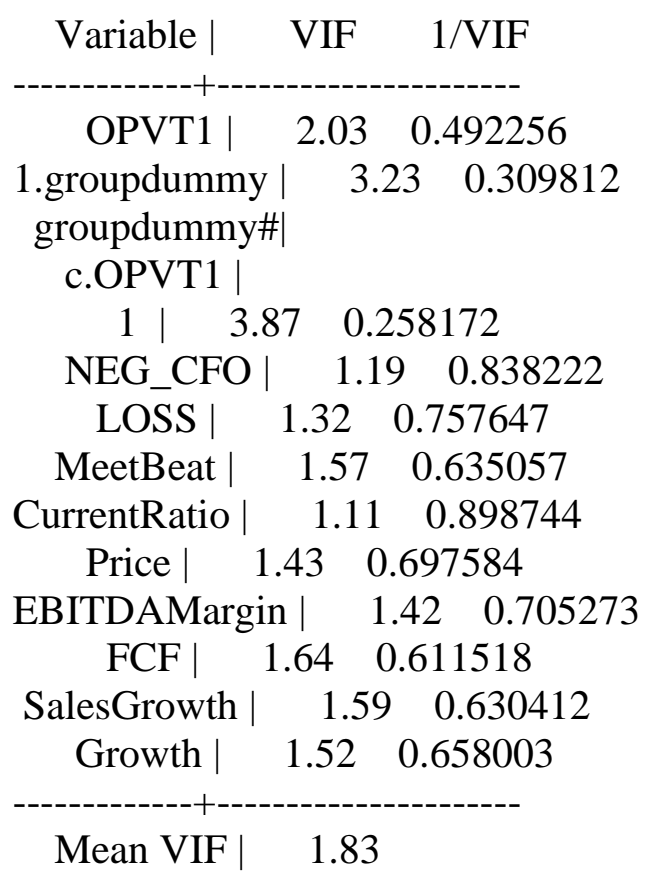

b) DACCi (INCOME DECREASING)

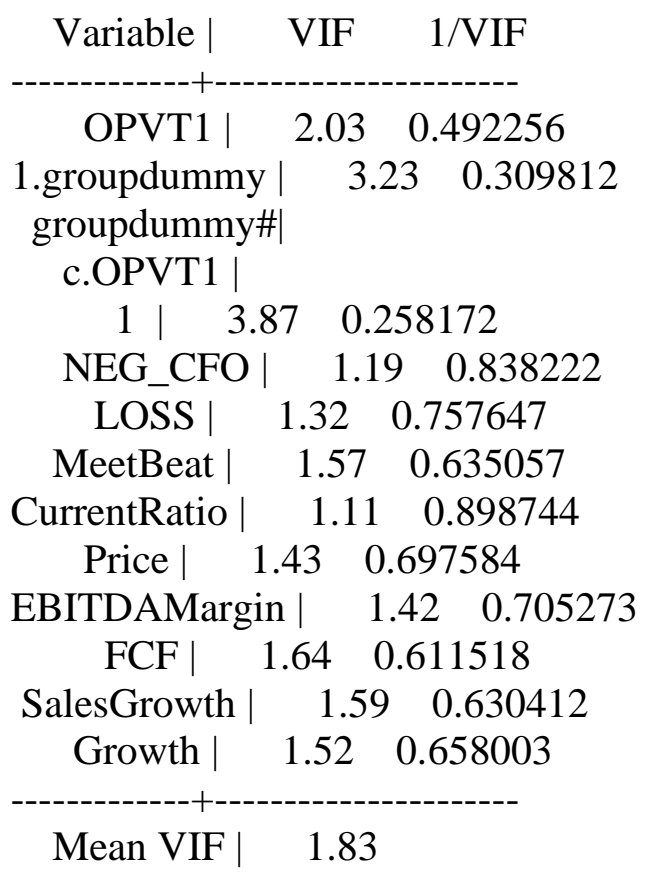


c) CACCi (Current Accrual)

\begin{tabular}{|c|c|c|}
\hline Variable | & VIF & $1 / \mathrm{VIF}$ \\
\hline OPVT1 & 2.03 & 0.492256 \\
\hline \multicolumn{3}{|c|}{$\begin{array}{c}\text { 1.groupdummy } \\
\text { groupdummy\# } \\
\text { c.OPVT1 }\end{array}$} \\
\hline $1 \mid$ & .87 & 258172 \\
\hline NEG_CF( & 1.1 & $9 \quad 0.838222$ \\
\hline LOSS | & 1.32 & 0.757647 \\
\hline MeetBeat & 1.57 & 0.635057 \\
\hline CurrentRatio & 1.11 & 0.898744 \\
\hline Price | & $1.43 \quad 0$ & .697584 \\
\hline EBITDAMar & & $\begin{array}{ll}1.42 & 0.705273\end{array}$ \\
\hline $\mathrm{FCF}$ & 1.640 & 0.611518 \\
\hline SalesGrowth & 1.59 & 0.630412 \\
\hline Growth | & 1.52 & 0.658003 \\
\hline Mean VI & 1.8 & \\
\hline
\end{tabular}

d) Non-Current Accrual

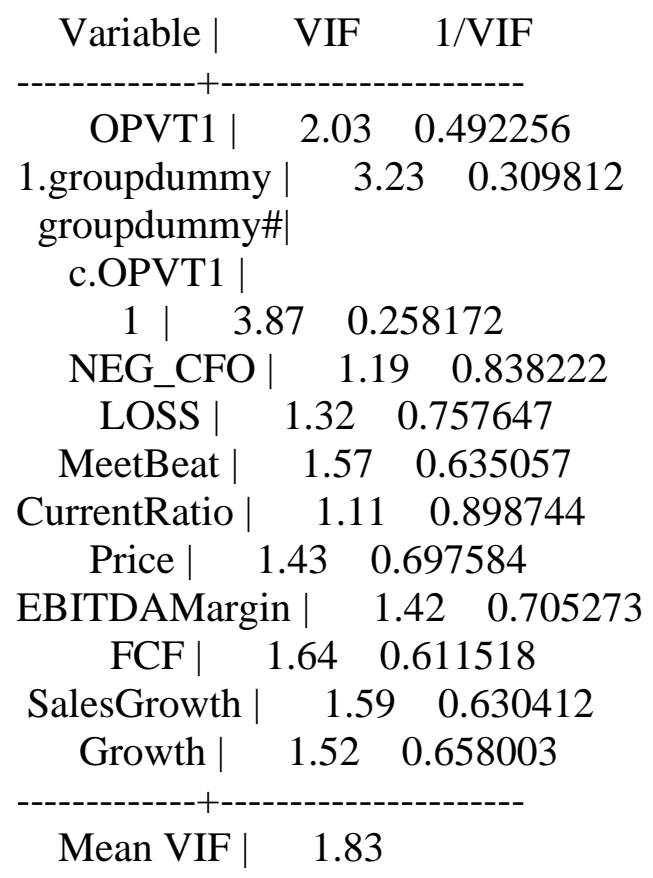




\section{iv. $\quad$ Regression result}

a) OLS Regression Discretionary Accrual

\begin{tabular}{|c|c|c|c|c|}
\hline Source | & SS & MS & $\begin{array}{c}\text { Number of obs }= \\
F(12118)\end{array}$ & 131 \\
\hline Mode & .1652 & 12.01 & 3772009 Prob > F & $=0.0000$ \\
\hline Residual | & 121208647 & 118.0( & 1027192 R-squared & $=0.5769$ \\
\hline & & 130.00 & 203637 Root MSE & $\begin{array}{l}0.5339 \\
=\quad .03205\end{array}$ \\
\hline
\end{tabular}

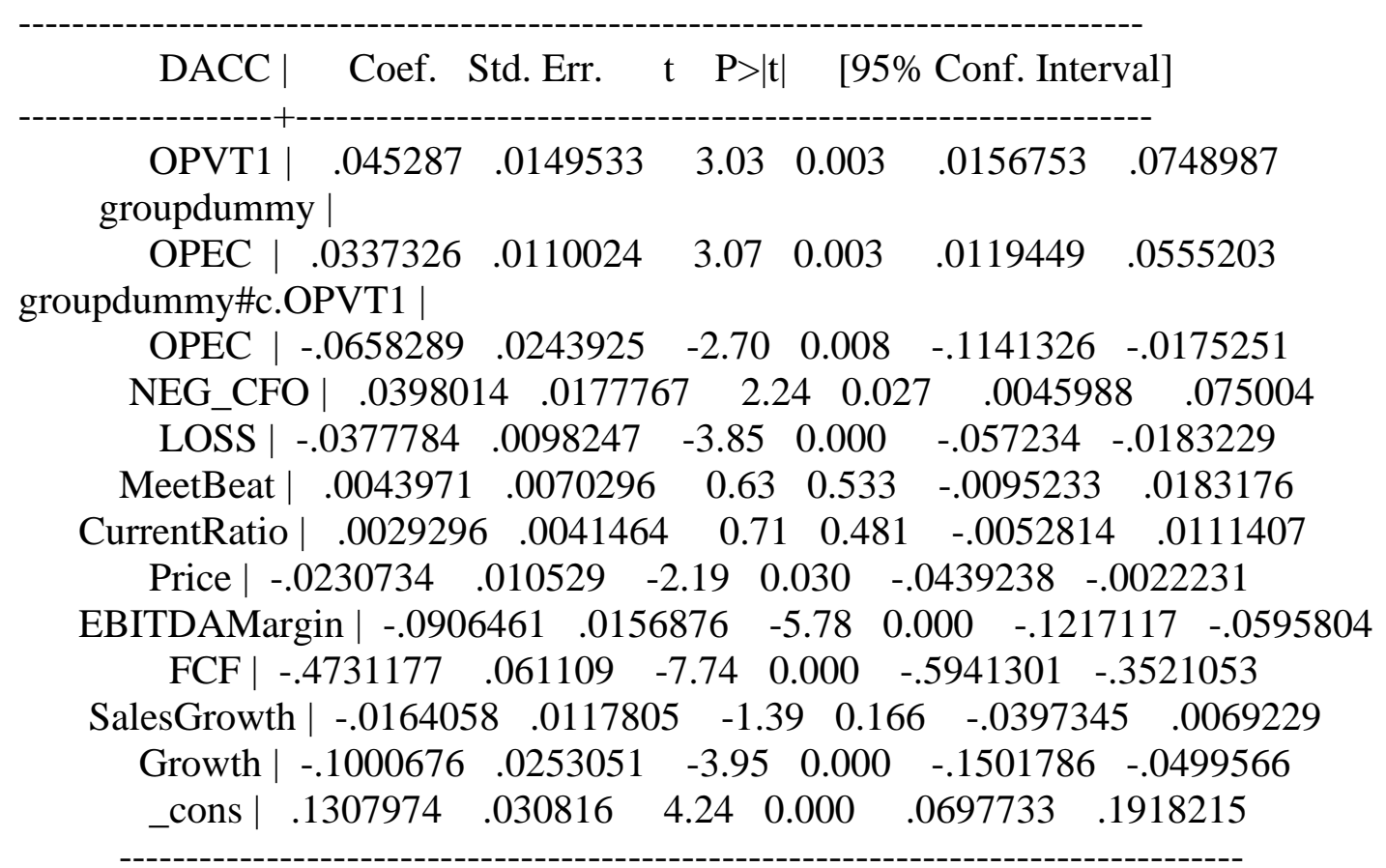

b) OLS Regression Income Decreasing Discretionary Accrual

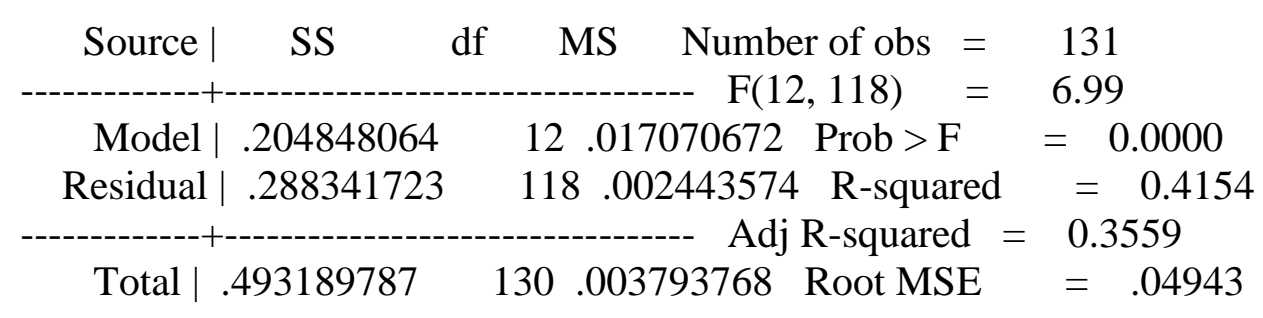

\begin{tabular}{|c|c|c|c|c|c|}
\hline DACCi $\mid$ & Coef. Std. Err. & $t \quad P>|t|$ & {$[95 \%$} & Conf. Interva & val] \\
\hline $\begin{array}{l}\text { OPVT1 | } \\
\text { groupdummy }\end{array}$ & |.0704997 .0230635 & -3.06 & 0.003 & -.1161716 & -.0248277 \\
\hline OPEC | & .0521169. 0169696 & -3.07 & 0.003 & $-.0857214-$ & -.0185124 \\
\hline
\end{tabular}




$$
\begin{aligned}
& \text { groupdummy\#c.OPVT1 | } \\
& \begin{array}{l|llllll}
\text { OPEC } & .0753092 & .0376221 & 2.00 & 0.048 & .0008072 & .1498112
\end{array} \\
& \text { NEG_CFO | } \begin{array}{lllllll}
0.0154469 & .0274181 & 0.56 & 0.574 & -.0388484 & .0697421
\end{array} \\
& \begin{array}{lllllll}
\text { LOSS } & .045242 & .0151533 & 2.99 & 0.003 & .0152344 & .0752496
\end{array} \\
& \begin{array}{l|llllll}
\text { MeetBeat } & .0041877 & .0108421 & 0.39 & 0.700 & -.0172826 & .0256581
\end{array} \\
& \begin{array}{l|llllll}
\text { CurrentRatio } & .0014786 & .0063953 & 0.23 & 0.818 & -.0111858 & .0141431
\end{array} \\
& \begin{array}{l|llllll}
\text { Price } & .0042796 & 0162396 & 0.26 & 0.793 & -.0278792 & .0364385
\end{array} \\
& \begin{array}{lllllll}
\text { EBITDAMargin | } & .1277528 & .024196 & 5.28 & 0.000 & .0798383 & .1756674
\end{array}
\end{aligned}
$$

\begin{tabular}{|c|c|c|c|c|}
\hline Source | & SS & MS & $\begin{aligned} \text { Number of obs } & = \\
-\mathrm{F}(12,118) & =\end{aligned}$ & $\begin{array}{r}131 \\
9.72\end{array}$ \\
\hline Model & .065663331 & 12.00 & 471944 Prob $>F$ & $=0.0000$ \\
\hline Residual | & .066457061 & 118.00 & 0563195 R-squared & $=0.4970$ \\
\hline otal & 92 & 130.001 & 16311 Root MSE & $=.02373$ \\
\hline
\end{tabular}

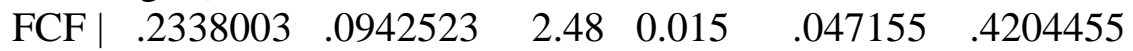

$$
\begin{aligned}
& \begin{array}{lllllll}
\text { SalesGrowth | } & .0326858 & .0181699 & 1.80 & 0.075 & -.0032956 & .0686671
\end{array} \\
& \begin{array}{lllllll}
\text { Growth | } & .0525543 & .0390297 & 1.35 & 0.181 & -.0247352 & .1298437
\end{array} \\
& \begin{array}{lllllll}
\text { _cons | } & -.0729058 & 0475295 & -1.53 & 0.128 & -.1670272 & .0212156
\end{array}
\end{aligned}
$$

\section{c) OLS Regression of Current Accrual}

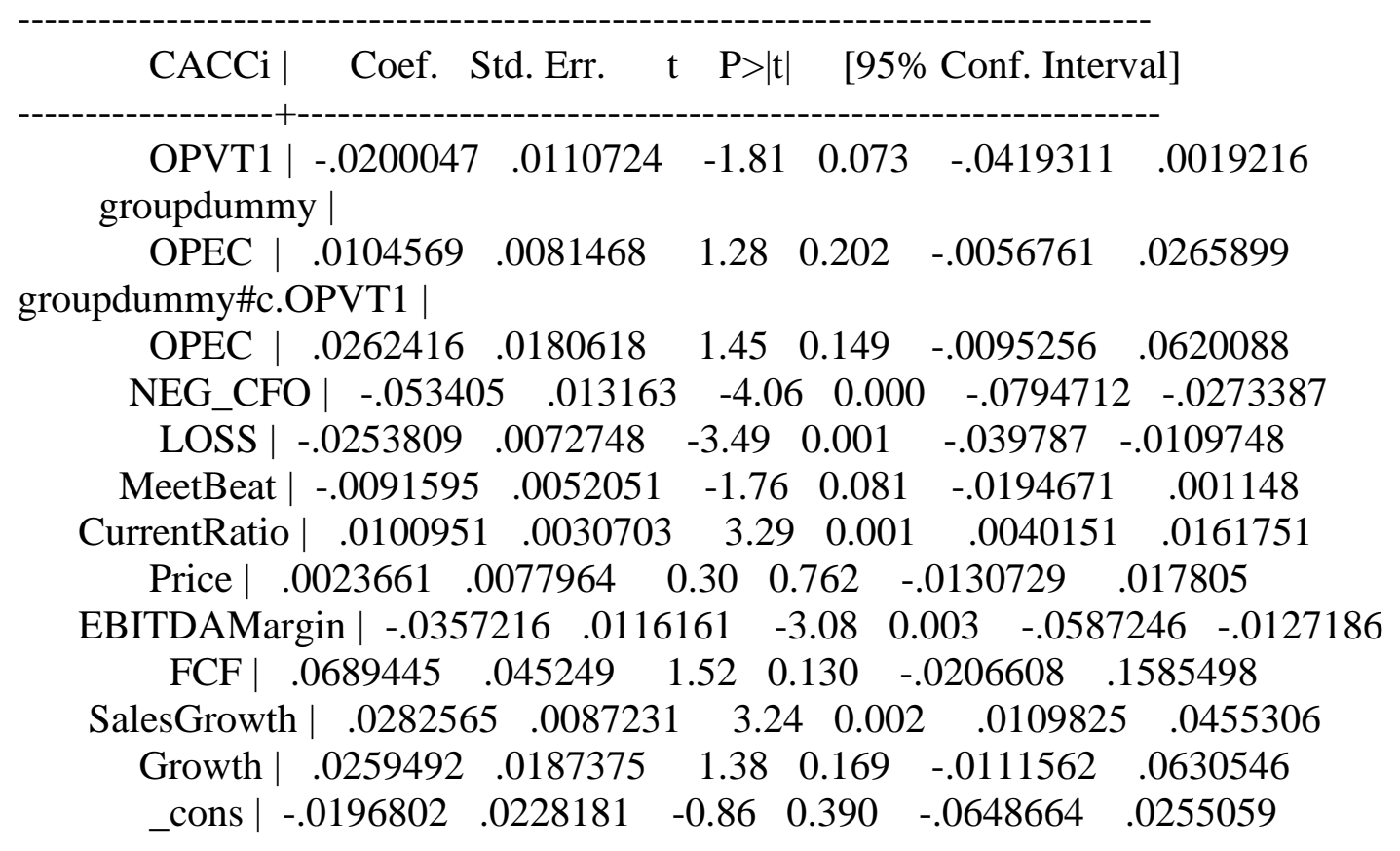




\section{d) OLS Regression of Non- Current Accrual}

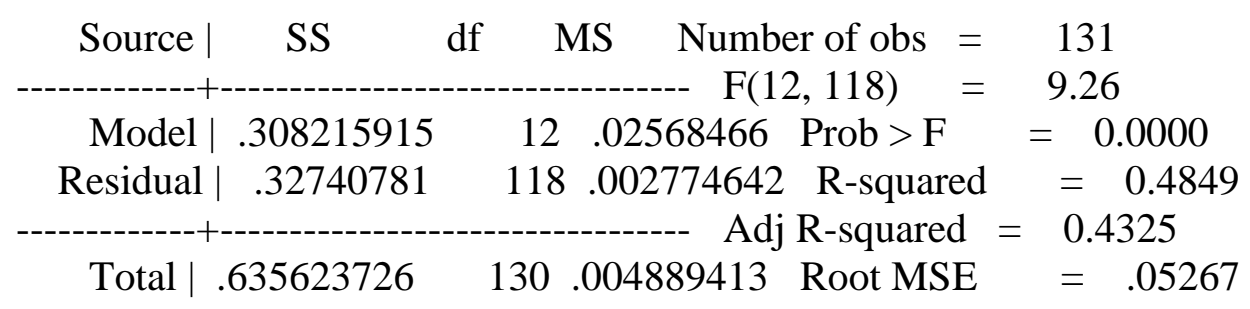

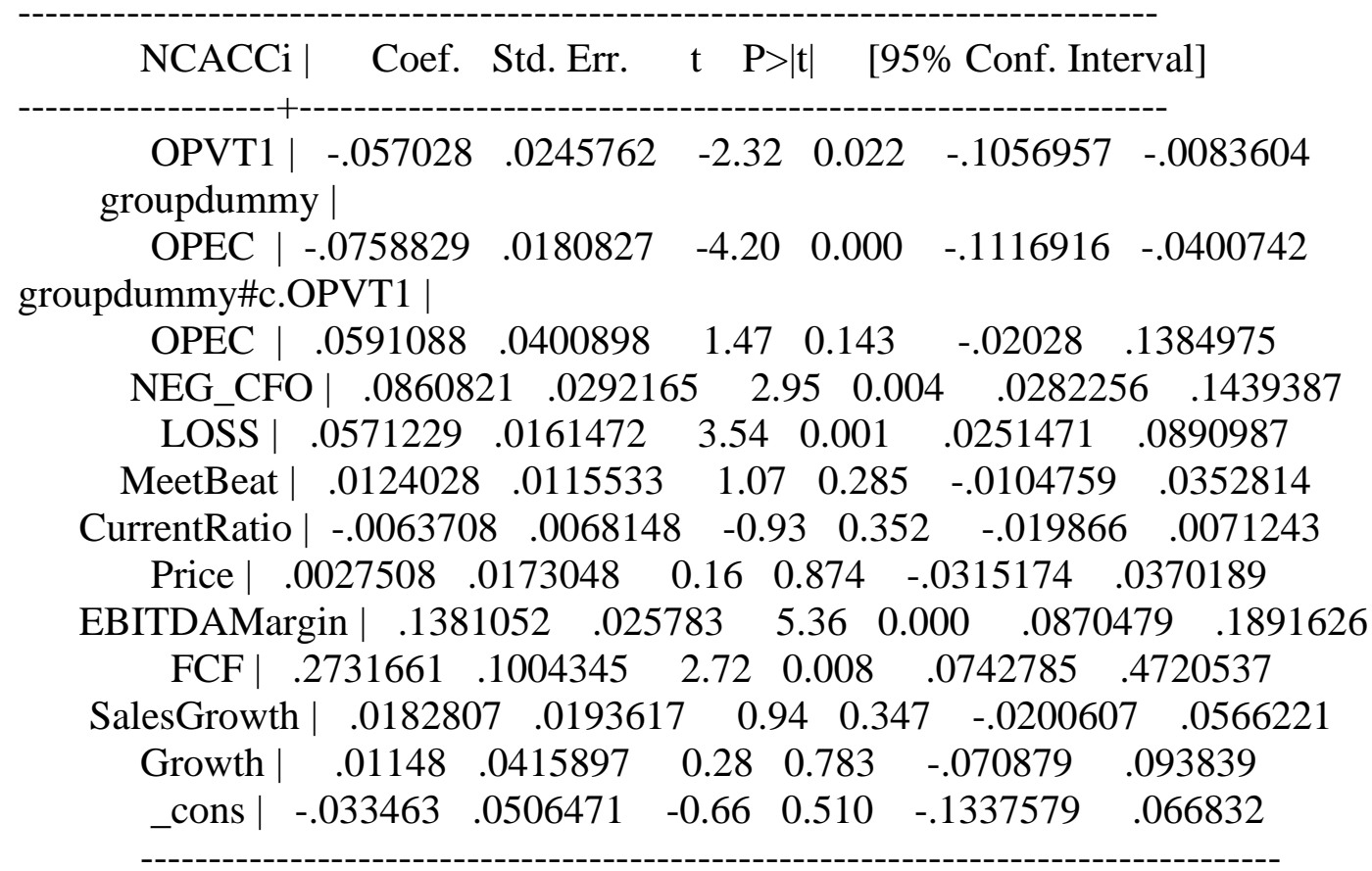

\section{i. Pearson Correlation}

LOSS MeetBeat

\section{DACC DACCi CACCi NCACCi OPVT1 groupd $\sim$ NEG_CFO}

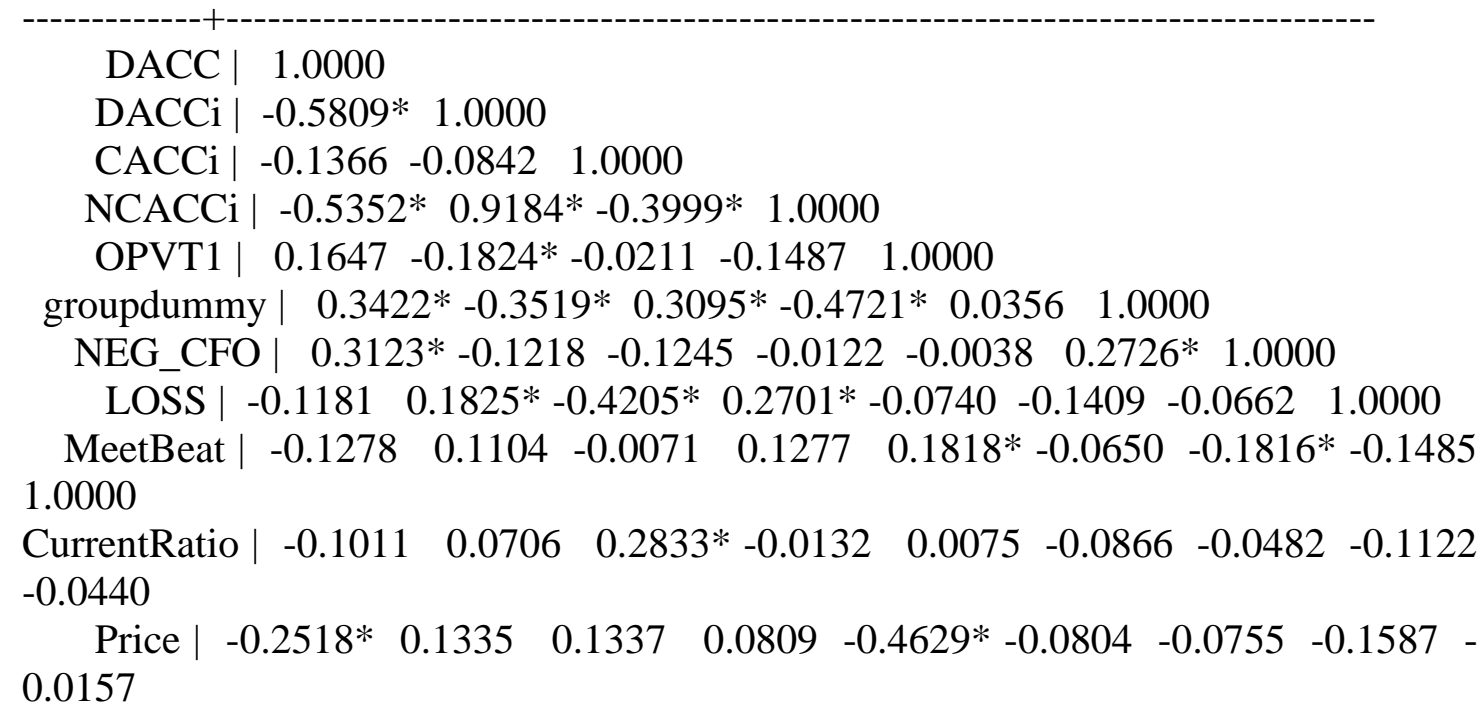


EBITDAMargin | $-0.3769 * 0.4843 *-0.2780 * 0.4514 *-0.0237 \quad-0.2884 *-0.1861 *$ 0.05730 .1349

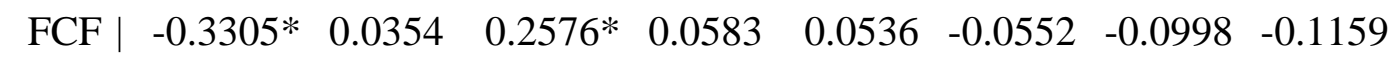
$0.2393^{*}$

$\begin{array}{llllllll}\text { SalesGrowth | } & -0.1582 & 0.1446 & 0.2629 * & 0.0696 & 0.2110 * & 0.0889 & 0.0826\end{array}$ $0.2607 * 0.4458 *$

\begin{tabular}{l|llllllll} 
Growth & -0.1144 & 0.1029 & 0.0984 & -0.0012 & 0.1187 & -0.0540 & 0.0316 & $-0.2755^{*}$
\end{tabular} 0.0420

| CurrentRatio Price EBITDAMargin FCF SalesGrowth Growth

CurrentRatio | 1.0000

\begin{tabular}{l|ll} 
Price & $0.0298 \quad 1.0000$
\end{tabular}

EBITDAMargin | $0.0262 \quad 0.0590 \quad 1.0000$

FCF | $0.2284 * 0.0297-0.3284 * 1.0000$

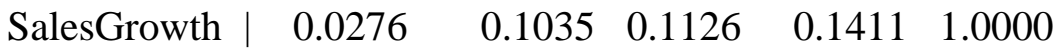

Growth | $0.0182 \quad 0.0446 \quad 0.2635^{*}-0.3513 * 0.2720 * 1.0000$ 